\title{
PERAN PEMBANGUNAN INFRASTRUKTUR DALAM PERTUMBUHAN EKONOMI WILAYAH KABUPATEN MEMPAWAH
}

\author{
Firsta Rekayasa Hernovianty ${ }^{a}$ \\ ${ }^{a}$ Universitas Tanjungpura, Indonesia \\ E-mail Korespondensi: teta.firsta02@gmail.com
}

\begin{abstract}
Abstrak: Pembangunan infrastruktur merupakan salah satu upaya yang mampu memicu pertumbuhan ekonomi di suatu wilayah. Kabupaten Mempawah sebagai daerah penyangga yang terletak diantara Kota Pontianak dan Kota Singkawang memiliki peluang untuk percepatan pembangunan infrastruktur. Namun, proses pembangunan infrastruktur masih terkendala karena adanya konflik pembebasan lahan, perencanaan dan pengawasan yang lemah, kuantitas yang belum mencukupi dan kualitas yang masih rendah. Penelitian ini bertujuan untuk mengetahui peran pembangunan infrastruktur dalam pertumbuhan ekonomi wilayah Kabupaten Mempawah. Teknik analisis menggunakan pendekatan kualitatif eksploratif yang menitikberatkan pada argumentasi dan bukti empiris yang diperoleh ketika survey. Hasil penelitian didapatkan bahwa pembangunan infrastruktur memiliki peran yang sangat penting dalam mempercepat pertumbuhan ekonomi Kabupaten Mempawah. Hal ini didukung dengan hasil analisis pertumbuhan ekonomi wilayah, dimana nilai PDRB Atas Dasar Harga Berlaku diproyeksikan akan mengalami peningkatan sebesar $\mathrm{Rp}$ 18.848,13 miliar pada tahun 2035. Adapun 5 lapangan usaha yang memiliki kontribusi terbesar adalah pertanian; administrasi pemerintahan, pertahanan, dan jaminan sosial wajib; industri pengolahan; perdagangan besar dan eceran serta konstruksi. Selain itu, berdasarkan rencana tata ruang Kabupaten Mempawah juga memiliki kawasan strategis dari sudut kepentingan percepatan pertumbuhan ekonomi yaitu Kawasan Ekonomi Khusus (KEK) dan Kawasan Industri (KI) Kecamatan Sungai Kunyit dan sekitarnya dimana arahan rencana difokuskan dalam pengembangan pelabuhan.
\end{abstract}

Keywords: Infrastruktur, Pertumbuhan Ekonomi, Pengembangan Wilayah

\begin{abstract}
Infrastructure development is one of efforts that can trigger economic growth in a region. Mempawah Regency as a buffer area located between Pontianak City and Singkawang City has the opportunity to accelerate infrastructure development. However, the infrastructure development process is still constrained by conflicts over land acquisition, weakness in planning and supervision, insufficient quantity and low quality of infrastructure. This study aims to determine the role of infrastructure development in the economic growth of Mempawah Regency. The analysis technique uses a qualitative exploratory approach that focused on arguments and empirical evidence obtained during the survey. The results showed that infrastructure development has a very important role in accelerating economic growth in Mempawah Regency. This is supported by the results of an analysis of regional economic growth, where the value of GRDP at the current price is projected to increase by Rp. 18,848.13 billion in 2035. The largest contribution of 5 sectors are agriculture; government administration, defense and social security; processing industr; , wholesale and retail as well as construction. In addition, based on the spatial plan, Mempawah Regency also has strategic areas in terms of the interest of accelerating economic growth, namely the Special Economic Zone (KEK) and Industrial Area (KI) of Sungai Kunyit District and its surroundings which the plan direction is focused on port development.
\end{abstract}

Keywords: Infrastructure, Economic Growth, Regional Development

How to cite (APA 6th Style):

Hernovianty, Firsta Rekayasa. (2021). Peran Pembangunan Infrastruktur dalam Pertumbuhan Ekonomi Wilayah Kabupaten Mempawah, 2(1), 9-16. 


\section{PENDAHULUAN}

Pertumbuhan ekonomi merupakan salah satu indikator kemajuan suatu wilayah. Salah satu faktor yang mendorong pertumbuhan ekonomi adalah sektor infrastruktur. Infrastruktur berpengaruh penting bagi peningkatan kualitas hidup dan kesejahteraan manusia, antara lain dalam peningkatan pendapatan regional, peningkatan produktivitas tenaga kerja dan akses kepada lapangan kerja. Pembangunan infrastruktur diyakini mampu menggerakkan sektor riil, menyerap tenaga kerja, meningkatkan konsumsi masyarakat dan pemerintah, serta memicu kegiatan produksi (Daroedono, 2004). Pembangunan infrastruktur yang berkualitas akan mampu mendorong pertumbuhan ekonomi, meningkatkan daya saing wilayah, mempermudah arus pergerakan orang dan barang sehingga menimbulkan multiplier effect yang positif bagi kesejahteraan penduduk. Pemberdayaan sumber daya untuk membangun infrastruktur akan memicu proses ekonomi sehingga menimbulkan penggandaan dampak ekonomi maupun sosial (Setiadi, 2006).

Kabupaten Mempawah memiliki letak yang strategis, berada di antara 2 (dua) kotamadya, yaitu Kota Pontianak dan Kota Singkawang. Hal ini menjadikan Kabupaten Mempawah sebagai wilayah pendukung (hinterland) Kota Pontianak yang dapat menampung limpahan kegiatan perkotaan dari ibukota Provinsi Kalimantan Barat tersebut. Perkembangan daerah perkotaan lebih pesat dibandingkan di pedesaan. Kawasan perkotaan Mempawah cenderung lebih cepat maju dibandingkan dengan wilayah sekitarnya. Perkotaan Mempawah dilintasi oleh Jalan Nasional yang memiliki kondisi sangat baik, namun sebaliknya dengan jalan dan jembatan di daerah pedesaan yang masih dapat ditemukan dalam keadaan rusak. Kondisi ini juga menyebabkan rendahnya aksesibilitas dan semakin tertinggalnya pembangunan di daerah perdesaan dan akhirnya meningkatkan ketimpangan ekonomi dan sosial antar wilayah.

Efisensi dalam aktivitas ekonomi perlu didukung oleh infrastruktur yang memadai untuk meningkatkan potensi daerah masing-masing secara optimal dan berkesinambungan. Pengembangan potensi lokal dapat mendorong peningkatan produktivitas daerah sesuai dengan kemampuannya sehingga dapat memajukan proses pembangunan wilayah secara merata. Walaupun pembangunan infrastruktur di Kabupaten Mempawah telah berkontribusi dalam peningkatan pertumbuhan ekonomi, namun masih banyak masalah yang dihadapi, antara lain perencanaan yang lemah, kuantitas yang belum mencukupi dan kualitas yang masih rendah (Ikhsan, 2004). Keterpurukan pembangunan infrastruktur bukan hanya disebabkan oleh faktor internal, seperti minimnya anggaran pemerintah di sektor pembangunan, namun juga berasal dari faktor-faktor eksternal. Masih banyak ditemukan beberapa kasus pembangunan infrastruktur yang terancam gagal karena terganjal oleh pada kompleksitas pertanahan, baik dari aspek perizinan maupun penggunaan dan pemanfaatan tanah. Dengan demikian, perlu adanya penelitian yang bertujuan untuk mengkaji lebih dalam peran pembangunan infrastruktur dalam pertumbuhan ekonomi wilayah Kabupaten Mempawah, dengan menganalisis laju pertumbuhan ekonomi dan kondisi perkembangan infrastruktur Kabupaten Mempawah.

\section{DATA AND METHODE}

\subsection{Data}

Tahapan penelitian yang dilakukan dalam penelitian ini dimulai dari tahap persiapan, tahap pengumpulan data, dan tahap analisis. Untuk lebih jelasnya, tahapan penelitian akan diuraikan sebagai berikut :

1) Tahap Persiapan merupakan kajian awal terhadap peraturan dan kebijakan terkait penelitian, begitu juga dengan studi literatur dan penelitian terdahulu yang pernah dalam hal pembangunan infrastruktur dan pertumbuhan ekonomi. Dengan diperolehnya gambaran teoritis dan praktis tentang hubungan pembangunan infrastruktur dan pertumbuhan ekonomi, maka diharapkan hasil yang diperoleh dapat optimal dan sesuai dengan aturan yang ada.

2) Tahap Kompilasi Data merupakan proses pengumpulan data dengan menggunakan teknik pengumpulan data primer dan sekunder. Data primer diperoleh dengan melakukan observasi langsung ke proyek pembangunan infrastruktur yang strategis di Kabupaten Mempawah dan wawancara key informan agar mendapat argumentasi terkait potensi dan masalah dalam perencanaan maupun 
pembangunan infrastruktur. Sedangkan data sekunder diperoleh dari kajian literatur dan kebijakankebijakan terkait percepatan pembangunan infrastruktur untuk peningkatan ekonomi daerah.

3) Tahap Analisis merupakan hasil pengumpulan data yang diperoleh pada tahap sebelumnya, kemudian data tersebut dianalisis. Analisis ini bertujuan untuk memperoleh gambaran tentang kendala dan peran pembangunan infrastruktur dalam memajukan ekonomi Kabupaten Mempawah.

\subsection{Methode}

Pendekatan penelitian ini adalah pendekatan kualitatif fenomenologis, tentang peran pembangunan infrastruktur dalam memajukan ekonomi Kabupaten Mempawah. Penelitian ini menggunakan metode rasionalistik yang berdasarkan pada pola berpikir rasionalisme, yang berasal dari pemahaman kemampuan intelektual dan dibangun atas kemampuan argumentasi secara logika, sehingga lebih ditekankan pada pemaknaan empiris (Hadi, 1984). Analisis data menggunakan pendekatan kualitatif eksploratif yang menitikberatkan pada argumentasi dan bukti empiris yang diperoleh ketika survey. Hal ini juga didukung dengan konsep teoritis yang disajikan secara sistematis dan terarah agar mendapatkan hasil pengamatan yang sesuai dengan tujuan penelitian yaitu, peran pembangunan infrastruktur dalam memajukan ekonomi Kabupaten Mempawah.

\section{HASIL DAN PEMBAHASAN}

\subsection{Tinjauan Kebijakan}

Adapun kebijakan yang akan ditinjau dalam penelitian ini adalah Peraturan Daerah Nomor 3 Tahun 2014 Tentang Rencana Tata Ruang Wilayah Kabupaten Mempawah Tahun 2014-2034. Hal ini dilakukan untuk melihat kedudukan dan peran wilayah Kabupaten Mempawah dalam konstelasi nasional dan regional, sehingga mendapatkan gambaran sejauh mana perkembangan infrastruktur berpengaruh dalam mempercepat pertumbuhan wilayah. Beberapa kawasan strategis yang ada di Kabupaten Mempawah antara lain :

a. Kawasan Strategis Nasional adalah kawasan strategis dari sudut kepentingan pendayagunaan sumberdaya alam dan teknologi tinggi yaitu Kawasan Stasiun Pengamat Dirgantara Pontianak yang terdapat di Kecamatan Siantan.;

b. Kawasan Strategis Provinsi adalah kawasan strategis dari sudut kepentingan pertumbuhan ekonomi di Kawasan Pelabuhan Utama Temajo dan sekitarnya di Kecamatan Sungai Kunyit dengan sektor unggulan industri pengolahan bauksit dan industri lainnya.; dan

c. Kawasan Strategis Kabupaten meliputi kawasan yang memiliki nilai strategis dari sudut kepentingan pertumbuhan ekonomi, yaitu kawasan sub pusat perdagangan dan jasa di Kecamatan Sungai Pinyuh dan kawasan industri di Kecamatan Sungai Kunyit dan Siantan; dan kawasan yang memiliki nilai strategis dari sudut kepentingan sosial budaya terdiri atas Kawasan Keraton Amantubillah, Makam Habib Husein di Kecamatan Mempawah Timur dan Sebukit di Kecamatan Mempawah Hilir.

\subsection{Analisis Pertumbuhan Ekonomi Wilayah}

Perekonomian regional pada umumnya dibahas dengan menggunakan indikator pendapatan regional (PDRB), yang dalam hal ini diambil dalam satuan nilai tambah. PDRB disajikan dalam dua bentuk, yaitu menurut harga yang berlaku dan menurut harga konstan tahun tertentu. Pertumbuhan ekonomi Kabupaten Mempawah pada tahun 2019 tumbuh melambat dibanding pertumbuhan pada tahun 2018. Berdasarkan hasil perhitungan PDRB atas dasar harga konstan tahun 2010, laju pertumbuhan ekonomi Kabupaten Mempawah tahun 2019 sebesar 5,81 persen. Nilai PDRB atas dasar harga konstan 2010 pada tahun 2019 mencapai Rp 5.246,18 milliar, meningkat dibandingkan tahun 2018 yang hanya mencapai Rp 4.958,28 milliar.

Dilihat dari struktur perekonomian, lapangan usaha pertanian, kehutanan dan perikanan merupakan lapangan usaha yang mempunyai kontribusi terbesar dalam pembentukan PDRB dalam beberapa tahun terakhir. Pada tahun 2019 tercatat konstribusi lapangan usaha pertanian, kehutanan dan perikanan sebesar 24,62 persen terhadap keseluruhan perekonomian yang ditunjukkan pada PDRB harga berlaku tahun tersebut. Kemudian disusul oleh lapangan usaha industri pengolahan 15,97 persen, lapangan usaha 
administrasi pemerintahan, pertahanan dan jaminan sosial sebesar 15,68 persen; lapangan usaha perdagangan besar dan eceran sebesar 15,62 persen; serta 13 lapangan usaha lainnya sebesar 28,10 persen.

Pola Struktur ini relatif masih tetap sama dibanding tahun sebelumnya, dimana lapangan usaha Pertanian, kehutanan dan perikanan kontribusinya mengalami penurunan setiap tahunnya, sedangkan konstribusi industri pengolahan mengalami peningkatan dalam 4 tahun terakhir. Selain itu, lapangan usaha konstruksi juga menunjukkan adanya peluang peningkatan dalam kurun waktu terakhir. Hal ini dapat diindikasikan karena adanya pembangunan proyek-proyek strategis yang sedang berlangsung di Kabupaten Mempawah.

Tabel 1. Kontribusi Produk Domestik Regional Bruto Atas Dasar Harga Berlaku Kabupaten Mempawah (miliar rupiah) Tahun 2015 - 2019 (Badan Pusat Statistik Kabupaten Mempawah, 2020)

\begin{tabular}{|c|c|c|c|c|c|c|}
\hline No & Lapangan Usaha & 2015 & 2016 & 2017 & 2018 & 2019 \\
\hline A & Pertanian. Kehutanan dan Perikanan & 26,23 & 25,88 & 25,44 & 24,98 & 24,62 \\
\hline B & Pertambangan dan Penggalian & 1,07 & 1,09 & 1,10 & 1,11 & 1,09 \\
\hline C & Industri Pengolahan & 15,98 & 15,73 & 15,85 & 15,96 & 15,97 \\
\hline D & Pengadaan Listrik dan Gas & 0,23 & 0,27 & 0,29 & 0,31 & 0,33 \\
\hline $\mathbf{E}$ & $\begin{array}{l}\text { Pengadaan Air; Pengelolaan Sampah. } \\
\text { Limbah. dan Daur Ulang }\end{array}$ & 0,13 & 0,12 & 0,12 & 0,12 & 0,12 \\
\hline $\mathbf{F}$ & Konstruksi & 8,16 & 8,49 & 8,74 & 8,87 & 9,04 \\
\hline G & $\begin{array}{l}\text { Perdagangan Besar dan Eceran; } \\
\text { Reparasi Mobil dan Sepeda Motor }\end{array}$ & 15,49 & 15,47 & 15,46 & 15,49 & 15,62 \\
\hline $\mathrm{H}$ & Transportasi dan Pergudangan & 2,18 & 2,12 & 2,08 & 2,05 & 2,04 \\
\hline$I$ & $\begin{array}{l}\text { Penyediaan Akomodasi dan Makan } \\
\text { Minum }\end{array}$ & 2,30 & 2,27 & 2,23 & 2,25 & 2,22 \\
\hline $\mathbf{J}$ & Informasi dan Komunikasi & 1,57 & 1,58 & 1,69 & 1,76 & 1,79 \\
\hline K & Jasa Keuangan dan Asuransi & 3,23 & 3,34 & 3,31 & 3,32 & 3,09 \\
\hline $\mathbf{L}$ & Real Estat & 3,47 & 3,52 & 3,42 & 3,38 & 3,30 \\
\hline M.N & Jasa Perusahaan & 0,71 & 0,70 & 0,67 & 0,66 & 0,65 \\
\hline 0 & $\begin{array}{l}\text { Administrasi Pemerintahan, } \\
\text { Pertahanan, dan Jaminan Sosial Wajib }\end{array}$ & 14,41 & 14,73 & 15,11 & 15,29 & 15,68 \\
\hline $\mathbf{P}$ & Jasa Pendidikan & 2,43 & 2,38 & 2,26 & 2,23 & 2,20 \\
\hline $\mathbf{Q}$ & Jasa Kesehatan dan Kegiatan Sosial & 1,58 & 1,52 & 1,45 & 1,44 & 1,47 \\
\hline R.S.T.U & Jasa Lainnya & 0,84 & 0,81 & 0,78 & 0,78 & 0,78 \\
\hline \multicolumn{2}{|r|}{ Produk Domestik Regional Bruto } & 100,01 & 100,02 & 100,00 & 100,00 & 100,01 \\
\hline
\end{tabular}

Tabel 2. Proyeksi Produk Domestik Regional Bruto Atas Dasar Harga Berlaku Kabupaten Mempawah (miliar rupiah) Tahun 2020 - 2035 (analisis, 2020)

\begin{tabular}{|c|l|c|c|c|c|}
\hline No & \multicolumn{1}{|c|}{ Lapangan Usaha } & $\mathbf{2 0 2 0}$ & $\mathbf{2 0 2 5}$ & $\mathbf{2 0 3 0}$ & $\mathbf{2 0 3 5}$ \\
\hline A & Pertanian. Kehutanan. dan Perikanan & $2.184,19$ & $2.881,98$ & $3.579,76$ & $4.277,55$ \\
\hline B & Pertambangan dan Penggalian & 97,96 & 135,23 & 172,49 & 209,75 \\
\hline C & Industri Pengolahan & $1.431,64$ & $1.957,86$ & $2.484,09$ & $3.010,31$ \\
\hline D & Pengadaan Listrik dan Gas & 30,76 & 48,65 & 66,53 & 84,42 \\
\hline E & $\begin{array}{l}\text { Pengadaan Air; Pengelolaan Sampah. } \\
\text { Limbah. dan Daur Ulang }\end{array}$ & 10,27 & 13,32 & 16,37 & 19,42 \\
\hline F & Konstruksi & 822,30 & $1.182,17$ & $1.542,05$ & $1.901,92$ \\
\hline
\end{tabular}




\begin{tabular}{|c|c|c|c|c|c|}
\hline G & $\begin{array}{l}\text { Perdagangan Besar dan Eceran; } \\
\text { Reparasi Mobil dan Sepeda Motor }\end{array}$ & $1.401,68$ & $1.925,23$ & $2.448,78$ & $2.972,33$ \\
\hline $\mathrm{H}$ & Transportasi dan Pergudangan & 180,96 & 238,63 & 296,29 & 353,95 \\
\hline I & $\begin{array}{l}\text { Penyediaan Akomodasi dan Makan } \\
\text { Minum }\end{array}$ & 197,61 & 264,60 & 331,58 & 398,57 \\
\hline J & Informasi dan Komunikasi & 163,19 & 237,63 & 312,06 & 386,50 \\
\hline K & Jasa Keuangan dan Asuransi & 274,45 & 365,62 & 456,80 & 547,97 \\
\hline $\mathbf{L}$ & Real Estat & 293,14 & 389,46 & 485,77 & 582,08 \\
\hline M.N & Jasa Perusahaan & 57,47 & 74,99 & 92,50 & 110,01 \\
\hline 0 & $\begin{array}{l}\text { Administrasi Pemerintahan, } \\
\text { Pertahanan, dan Jaminan Sosial Wajib }\end{array}$ & $1.423,42$ & $2.030,11$ & $2.636,79$ & $3.243,48$ \\
\hline $\mathbf{P}$ & Jasa Pendidikan & 193,95 & 249,94 & 305,92 & 361,91 \\
\hline $\mathbf{Q}$ & Jasa Kesehatan dan Kegiatan Sosial & 130,43 & 171,58 & 212,73 & 253,88 \\
\hline R.S.T.U & Jasa Lainnya & 69,36 & 90,93 & 112,51 & 134,08 \\
\hline \multicolumn{2}{|r|}{ Produk Domestik Regional Bruto } & $8.962,76$ & $12.257,88$ & $15.553,01$ & $18.848,13$ \\
\hline
\end{tabular}

Perkembangan PDRB atas dasar harga berlaku dari tahun 2015-2019, dapat dijadikan sebagai dasar pertimbangan untuk memprediksi peningkatan PDRB di Kabupaten Mempawah untuk 20 tahun ke depan. Pada tahun 2035 diproyeksikan bahwa PDRB Kabupaten Mempawah akan mengalami peningkatan sebesar Rp 18.848,13 miliar. Dapat dilihat bahwa ada kecenderungan peluang kontribusi dari 5 lapangan usaha, yaitu pertanian sebesar Rp 4.277,55 miliar, administrasi pemerintahan, pertahanan, dan jaminan sosial wajib sebesar Rp 3.243,48 miliar, industri pengolahan sebesar Rp 3.010,31 miliar, perdagangan besar dan eceran sebesar Rp 2.972,33 miliar serta konstruksi Rp 1.901,92 miliar. Kelima lapangan usaha tersebut diharapkan dapat memacu pertumbuhan ekonomi wilayah Kabupaten Mempawah di masa yang akan datang.

\subsection{Konsep Ruang Pembangunan Infrastruktur Kabupaten Mempawah}

Dalam kurun waktu terakhir, banyak terdapat dinamika pembangunan infrastruktur yang mempengaruhi pertumbuhan ekonomi dan pengembangan wilayah Kabupaten Mempawah. Salah satu pembangunan infrastruktur yang diprediksikan akan memberikan kontribusi tinggi dalam perencanaan wilayah Kabupaten Mempawah, yaitu pembangunan Kawasan Strategis Provinsi dan Kabupaten Sungai Kunyit. Peraturan Daerah Nomor 10 Tahun 2014 Tentang Rencana Tata Ruang Wilayah Provinsi Kalimantan Barat Tahun 2014-3024 menetapkan 18 Kawasan Strategis Provinsi (KSP). Salah satu diantaranya adalah Kawasan Strategis Provinsi (KSP) Kecamatan Sungai Kunyit dan sekitarnya yang ditetapkan berdasarkan sudut kepentingan pertumbuhan ekonomi dimana sektor unggulan yang dikembangkan yaitu industri pengolahan. Dalam mewujudkan kawasan strategis tersebut, arahan rencana difokuskan dalam pengembangan pelabuhan.

Berdasarkan Peraturan Presiden RI Nomor 56 Tahun 2018 tentang Perubahan Kedua Atas Perpres No 3 Tahun 2016 tentang Percepatan Pelaksanaan Proyek Strategis menetapan pengembangan Pelabuhan/Terminal Kijing sebagai salah satu proyek strategis nasional. RTRW Provinsi Kalimantan Barat Tahun 2014-2034 juga menetapkan beberapa kebijakan dalam mendukung perwujudan KSP Sungai Kunyit, antara lain:

- Penetapan PKL Sungai Kunyit sebagai kawasan perkotaan yang melayani satu atau beberapa kecamatan;

- Rencana pengembangan terminal barang di Sungai Kunyit sebagai pusat distribusi barang dari/menuju Pelabuhan;

- Jalan Kolektor Primer (K1) yang melewati Sungai Pinyuh - Mempawah - Sungai Duri - Singkawang - Sambas akan dikembangkan menjadi jalan Arteri Primer; 
- Rencana jaringan kereta api lintas Utara, yaitu rute Pontianak - Sungai Pinyuh - Mempawah Singkawang - Pemangkat - Sambas - Aruk;

- Rencana jaringan kereta api khusus, yaitu rute Toho - Sungai Kunyit (pertambangan);

- Rencana pengembangan PLTU Gambut Mempawah sebesar 3 x 67 MW (2017); dan

- Rencana pengembangan pelabuhan utama yang merupakan pelabuhan İnternasional, yaitu Pelabuhan Pontianak di Kota Pontianak \& Terminal Temajok sebagai bagian dari Pelabuhan Pontianak yang dikembangkan di Kecamatan Sungai Kunyit Kabupaten Mempawah.

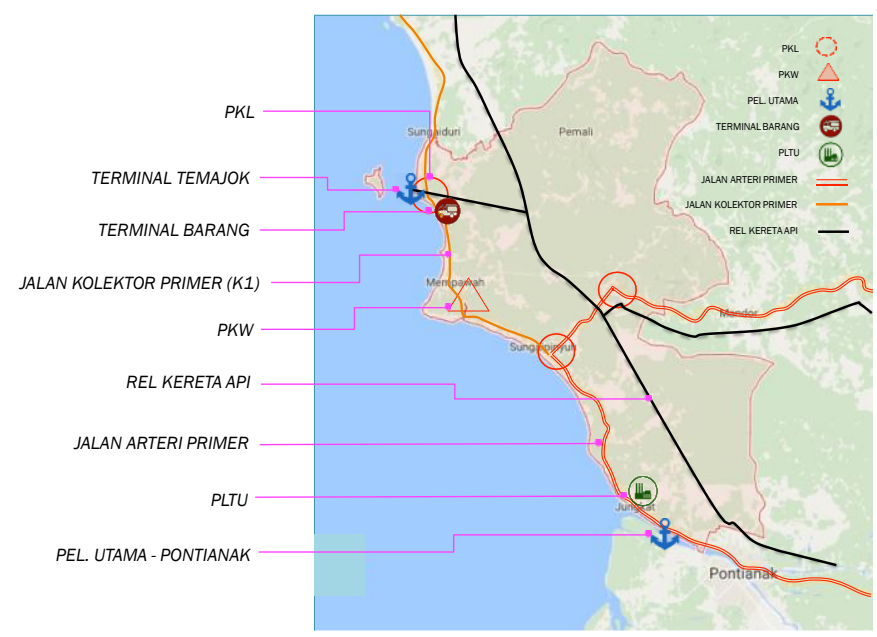

Gambar 1. Kedudukan KSP Sungai Kunyit

dalam RTRW Kalimantan Barat (Dinas PUPR Provinsi Kalimantan Barat, 2019)

Letak geografis Kabupaten Mempawah yang memiliki kawasan pesisir memanjang membuat lokasi lebih strategis untuk bongkar muat kapal barang. Tingginya ketersediaan lahan dan potensi sumber daya alam yang melimpah juga dapat dimanfaatkan untuk meningkatkan produktivitas ekonomi Kabupaten Mempawah. Selain itu, dukungan kebijakan pembangunan baik dari lingkup nasional maupun lingkup provinsi, memberikan peluang pelaksanaan pembangunan KSP Sungai Kunyit akan lebih mudah. Dengan adanya Kawasan Pelabuhan Kecamatan Sungai Kunyit dan sekitarnya diharapkan dapat menjadi pusat pertumbuhan baru di Kabupaten Mempawah. Adapun tantangan pengembangan infrastruktur adalah kebutuhan untuk mempercepat pengembangan dan peningkatan jaringan infrastruktur, ketimpangan intra wilayah Kabupaten Mempawah, pengembangan sumberdaya manusia yang masih terbatas dan sistem pengelolaan kawasan yang masih tumpang tindih.

Mengacu pada peran dan fungsi pengembangan KSP Sungai Kunyit, maka konsep ruang Kabupaten Mempawah diarahkan pada integrasi pengembangan Kawasan Ekonomi Khusus (KEK) yang memadukan kegiatan ekonomi utama, yaitu: Port development, Industrial estate dan Urban and recreational development. Hal ini diterapkan dalam kerangka konsep pengembangan integrated seaport development dengan memperhatikan prinsip pembangunan berkelanjutan. Seaport development adalah konsep pengembangan kawasan pelabuhan sebagai pusat kegiatan ekonomi dan pendukungnya. Pengembangan seaport development di Kawasan Sungai Kunyit diarahkan pada:

- Pengembangan baru (development)

- Fungsi campuran (mixed-used): pelabuhan, kawasan industri, permukiman, komersial dan pariwisata

- Dikembangkan dengan menggunakan 3 pilar pembangunan berkelanjutan (fisik/lingkungan, ekonomi, sosial).

Kawasan Ekonomi Khusus (KEK) adalah kawasan dengan batas tertentu dalam wilayah hukum NKRI yang ditetapkan untuk menyelenggarakan fungsi perekonomian dan memperoleh fasilitas tertentu. Konsep dasar KEK adalah pemberian fasilitas pada penyiapan kawasan yang lokasinya mempunyai aksesibilitas ke pasar global (akses ke pelabuhan dan/atau bandara). Zona yang dapat dikembangkan dalam KEK, meliputi pengolahan ekspor, logistik, industri, pengembangan teknologi, pariwisata, energi, ekonomi lainnya. 
Pengembangan Pelabuhan Sungai Kunyit diarahkan sebagai pelabuhan barang sebagai bagian terintegrasi dari Pelabuhan Utama Internasional Pontianak.

Kawasan Strategis Provinsi (KSP) diarahkan pengembangannya sebagai kawasan ekonomi terpadu yang didukung oleh kegiatan ekonomi utama, yaitu pelabuhan internasional, kawasan industri, dan pariwisata. Melalui pengembangan ketiga kegiatan ekonomoi utama secara terpadu dan terintegrasi dalam satu kawasan, diharapkan kawasan tersebut dapat menjadi pusat pertumbuhan baru ekonomi. Hal ini juga dapat mendorong pertumbuhan ekonomi Provinsi Kalimantan Barat pada umumnya dan Kabupaten Mempawah pada khususnya serta pada gilirannya dapat meningkatkan kesejahteraan masyarakat. Kawasan dibangun dengan kriteria aman dari gangguan fisik termasuk bencana alam, nyaman untuk melakukan seluruh aktivitas, serta berkelanjutan.

Konsepsi pengembangan Kawasan Strategis dimaksudkan sebagai alat guna mendorong dan meningkatkan pertumbuhan ekonomi bagi suatu kawasan, sehingga wilayah sekitarnya dapat ikut berkembang. Hal ini dilakukan agar dapat mewujudkan tujuan pembangunan wilayah secara simultan, yaitu menurunkan disparitas intra dan antar wilayah dan meningkatkan daya saing wilayah. Fokus pembangunan tidak hanya pada kawasan cepat tumbuh, tetapi juga yang sedang tumbuh, dan kawasan yang selama ini pembangunan infrastrukturnya masih lambat. Keterpaduan pembangunan infrastruktur akan meningkatkan efektifitas alokasi anggaran dan efisiensi pelaksanaan pembangunan. Sehingga pembangunan infrastruktur akan lebih merata dan dapat menghapuskan ketimpangan sosial ekonomi wilayah Kabupaten Mempawah yang cenderung cepat tumbuh hanya di bagian pesisir dan kawasan perkotaan. Pengembangan infrastruktur dalam kontek pengembangan kawasan strategis akan mendukung hal berikut:

- Konektivitas, menghubungkan antar-kluster (perkotaan, industri, pelabuhan) untuk meningkatkan produktivitas, efisiensi, pelayanan logistik nasional, dan menurunkan kesenjangan antar-wilayah.

- Kawasan Perkotaan dan Industri, mendukung pertumbuhan ekonomi dan meningkatkan produktivitas dan efisiensi dalam pembangunan dan operasional, dan menciptakan kesempatan kerja.

- Hinterland, memfasilitasi produksi primer dan keterkaitan dengan pengolahan dan pelayanan.

- Masyarakat, meningkatkan kualitas lingkungan dan kehidupan, memfasilitasi penyediaan perumahan rakyat dan pengembangan kapasitas, dan memfasilitasi hubungan dan kecocokan antara SDM/tenaga kerja dan industri.

\section{KESIMPULAN}

Pemerintah Kabupaten Mempawah senantiasa memberikan prioritas bagi pembangunan dan berfungsinya infrastruktur dalam rangka mendukung percepatan kemajuan ekonomi wilayah. Berdasarkan analisis pertumbuhan ekonomi wilayah, Produk Domestik Bruto Atas Dasar Harga Berlaku Kabupaten Mempawah diproyeksikan akan mengalami peningkatan sebesar Rp 18.848,13 miliar pada tahun 2035. Adapun 5 lapangan usaha yang menunjukkan kecenderungan peluang kontribusi terbesar adalah pertanian sebesar 23\%, Administrasi Pemerintahan, Pertahanan, dan Jaminan Sosial Wajib sebesar 17\%, industri pengolahan, perdagangan besar dan eceran sebesar $16 \%$ serta konstruksi sebesar $10 \%$. Berdasarkan RTRW Provinsi Kalimantan Barat dan RTRW Kabupaten Mempawah ditetapkan kawasan strategis dari sudut kepentingan percepatan pertumbuhan ekonomi yaitu Kawasan Ekonomi Khusus (KEK) dan Kawasan Industri (KI) Kecamatan Sungai Kunyit dan sekitarnya dimana arahan rencana difokuskan dalam pengembangan pelabuhan. Merujuk pada peran dan fungsi kawasan tersebut, maka konsep ruang Kabupaten Mempawah diarahkan pada integrasi pengembangan Kawasan Ekonomi Khusus (KEK) yang memadukan kegiatan ekonomi utama, yaitu: port development, industrial estate dan urban and recreational development. Dengan demikian, dapat disimpulkan pembangunan infrastruktur wilayah memiliki peran yang sangat penting dalam mempercepat pertumbuhan ekonomi Kabupaten Mempawah. Konsepsi pengembangan kawasan strategis bertujuan untuk mempercepat pertumbuhan ekonomi dan memicu produktivitas wilayah sekitar. Fokus pembangunan infrastruktur tidak hanya pada kawasan perkotaan cepat tumbuh, tetapi juga yang sedang tumbuh, serta kawasan pedalaman yang masih tertinggal. 


\section{UCAPAN TERIMA KASIH}

Terima kasih disampaikan kepada Fakultas Teknik Universitas Tanjungpura yang telah membantu pendanaan penelitian ini.

\section{DAFTAR PUSTAKA}

Badan Pusat Statistik. (2020). Kabupaten Mempawah Dalam Angka Tahun 2020

Daroedono. (2004). Pengembangan Lembaga Keuangan dan Investasi Infrastruktur. Info Kajian Bappenas, 31-42.

Dinas Pekerjaan Umum dan Penataan Ruang Provinsi Kalimantan Barat. (2019). Paparan Rencana Tata Ruang - Kawasan Strategis Provinsi Kawasan Kecamatan Sungai Kunyit Dsk.

Hadi, Sutrisno. (1984). Metodologi Reserarch, Jilid 1 dan 2. Yayasan Penerbit Fakultas Psikologi Universitas Gajah Mada. Yogyakarta.

Ikhsan. (2004). Hubungan Antara Infrastruktur dengan Pertumbuhan Ekonomi dan Pembangunan. LPEM, Jakarta.

Peraturan Daerah Provinsi Kalimantan Barat Nomor 10 Tahun 2014 Tentang Rencana Tata Ruang Wilayah Provinsi Kalimantan Barat Tahun 2014-3024

Peraturan Daerah Kabupaten Mempawah Nomor 3 Tahun 2014 Tentang Rencana Tata Ruang Wilayah Kabupaten Mempawah Tahun 2014-2034

Setiadi, Elen. (2006). Pengaruh Pembangunan Infrastruktur Dasar Terhadap Pertumbuhan Ekonomi Regional Indonesia (8 Provinsi di Sumatera). FEUI, Jakarta. 